Доц. др Алексеј Тимофејев

Универзитет у Београду

Филозофски факултет

Институт за новију историју Србије

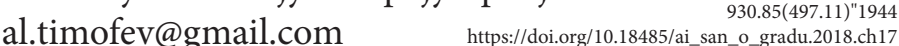

\title{
СЛИКА СРПСКОГ ГРАДА У УСПОМЕНАМА \\ И ДОКУМЕНТИМА ПРИПАДНИКА ЦРВЕНЕ АРМИЈЕ У ЈЕСЕН 1944.
}

Међу совјетским војницима и цивилима 1941-1943. постојао је драматичан осећај усамљености СССР-а у борби против Немаца и њихових савезника. Зато је онај ко се такође борио против Немаца од 1941. на сопственој територији, бранећи своје огњиште, природно стицао код совјетских војника позитиван имиџ. У овом контексту веома индикативан је однос према српским градовима, као градовима народа који се борио против заједничког непријатеља. С друге стране, постоји више примера снисходљивог сагледавања мањих димензија и релативно мирног ослобађања већине градова.

Кључне речи: Београд, Други светски рат у Србији, српско друштво у рату, Црвена армија, имагологија, руско-српски односи.

За војнике Црвене армије, као представнике совјетског и пре свега руског ${ }^{1}$ становништва, Београдска опера-

1 Две трећине црвеноармејаца (око 66\%) били су етнички Руси. Ова бројка би била још већа (око 75\%) ако узмемо у обзир руско становништво источне Украјине и Белорусије које је званична статистика водила као Украјинце и Белорусе. Россия и СССР в войнах ХХ века: Сйайистичческое исслеgование, Москва, 2001, с. 238. 
ција у јесен 1944. је била прва прилика да стекну представу о Југословенима и Србима, изгубљену после прекида традиција словенских веза у вртлогу екстремног левичарског експеримента (бољшевичке револуције). Слика створена у јесен 1944. ушла је у широке народне масе и, уз мање корекције, опстала је до модерног доба.

Неопходно је сагледати како су изгледали и ко су уопште били војници Црвене армије које су у септембру и октобру 1944. видели испред својих кућа становници источне и централне Србије, Београда и Војводине. Људи који су у редовима Црвене армије стигли на Балкан у јесен 1944. разликовали су се од оних „пререволуционарних Руса“. Револуција, грађански рат, успостављање тоталитарног режима са претензијама на месијанску ексклузивност нове идеологије водили су изолацији и издвајању Русије из породице европских народа. Само име Русија, услед Лењинових идеја о светској држави пролетера, нестаје и створен је нови назив - Савез Совјетских Социјалистичких Република. ${ }^{2}$ Због појачавања „шпијуноманије“ и спречавања било каквих контаката са странцима, без директне контроле органа државне безбедности, с једне стране, и због појачане пропаганде о патњама радне класе у капитализму и о успесима социјалистичке привреде, с друге стране, крајем тридесетих година велики део совјетског становништва имао је веома мало реалних представа о томе како је живео остатак Европе. Током тридесетих година 20. века Русија се претворила из полуаграрне земље у индустријског џина који је могао 1944. да

2 Детаљније о питању утицаја нове идеологије на руски народ видети у концептуалном научном раду: Вдовин А. И., Российская нация: Национально-йолитичческие ироблемы ХХ века и общенациональная российская ияея, Москва, 1995. и ново проширено издање истог аутора: Вдовин А. И., Русские в ХХ веке, Москва, 2004. 
произведе више наоружања него водећа индустријска сила Европе - Немачка, чија привреда се ослањала на индустријску и сировинску базу западне и централне Европе. Цену овог „индустријског чуда“ углавном су платили руски и украјински сељаци, али и целокупно становништва СССР-а, падом својих потрошачких могућности. С друге стране, и повећавање доступности здравствених и образовних услуга и културних установа неопходних за васпитање регрута за модерну војску такође је морало да се финансира из истих резерви. ${ }^{3}$

Прелазак совјетско-румунске границе за многе припаднике Црвене армије био је прва животна прилика да виде Европу и да упореде живот капитализма са достигнућима комунистичког система. ${ }^{4}$ Овај контакт је највише бринуо совјетско руководство, које је тежило да добије детаљне извештаје, преко својих политичких органа, о томе какав је утисак војника о иностранству. Исто тако тежило је да побољша и утисак који су остављали сами војници на становништво дела Европе ослобођеног од Немаца.

Војници и официри су представљали релативно младу популацију. Упадљива младост официрског кадра била је последица страшних губитака почетних година рата, када је скоро читав регуларни официрски кор погинуо у покушајима да се заустави немачка ратна машинерија. Официрски кадар Црвене армије - због губитака и мањка традиција и класних ограда - био је формиран уз помоћ убрзаних официрских курсева. Ово је деловало веома изненађујуће и на балканске кадровске официре које су први пут имали прилику да виде „потпуковника команданта бригаде, а два мајо-

3 Вишневский А., Серӣ и рубль. Консерватичвная моgернизация в СССР, Москва, 1998; Кондрашин В., Голоg 1932-1933 іоgов: Траіеgия российской веревни, Москва, 2008.

4 Слуцкий Б., „Записки о войне“, О gруїих и о сеઈе, Москва, 2005, c. $28-35$. 
ра су команданти пукова. Сви су млади људи, потпуковник има око 20, један мајор испод 30, а други једва 25 година“. ${ }^{5}$ Ово чуђење нису могли да не примете ни сами млади официри. ${ }^{6}$ Убрзана припрема официра била је надокнађена великим ратним искуством које су они стицали за време непрекидних и тешких борби али није увек могло да им пружи навике и особине које су имали кадровски официри. ${ }^{7}$

Официри и војници Црвене армије, осим свог релативно младог узраста, имали су још и једну општу особину - огроман и свеприсутан умор. Слаб отпор у Румунији и одсуство отпора у Бугарској нису спашавали пешадију од вишесатних ноћних маршева. Терет физичког напора и одговорности који је лежао на официрима и војницима био је претежак и за младе снаге. Овај замор од марширања већина војника је подносила ћутке али је умор прелазио све могуће границе и само понекад је долазило до гласног изражавања незадовољства. Гунђање у личним разговорима су забележили партијски организатори јединица. Редов 572. стрељачког пука Иван Наконечни, стар двадесет година, изјавио је: „Нас терају напред као стоку... по ноћи... одузимају нам могућност да се наспавамо или да запалимо, идемо по прашини, прљави, хранимо се скоро у покрету, насеља пролазимо по ноћи.... Редов 703. стрељачког пука Григориј Жужера је рекао: „Сваког дана пешачимо. Не дају нам да се одморимо како треба. А команданти траже без дозволе да не излазимо из колоне. Када ће томе бити крај?““

5 Пилетић В., Суgбина срӣскоі̄ официра, Крагујевац, 2002, с. 109.

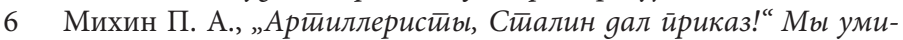
рали, чйобы йобеgит̄ъ, Москва, 2006, с. 370.

7 Зато је, уз велике напоре, Политичка управа Црвене армије покушавала да совјетском официрском корпусу експресно усади потребне манире и схватања. Кривицкий А., Русский обицер за рубежом, Москва, 1946.

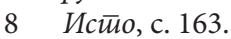


Физички и психички замор био је невероватан - од свог првог до последњег боја у Другом светском рату (28. фебруара 1942 - 28. фебруара 1945) војници 431. стрељачког пука 52. стрељачке дивизије су прешли више од 7.000 км, од предграђа Москве до центра Будимпеште. ${ }^{9}$ За разлику од километраже, бројевима се не може изразити стање борбеног стреса у ком су се налазили војници услед сталних борби, губитака другова, ризика од смрти или инвалидитета...

Совјетски војници су почели да заборављају реч „глад“ тек 1943-44. ${ }^{10}$ Тада нису гладовали углавном захваљујући „пронађеној“ храни и ратном плену. Могуће је завирити у кухињу тенкиста 4. гардијског механизованог корпуса генерала Жданова. На званичном менију у септембру 1944. су били: „доручак - гриз, ручак - купус чорба (боршч) са месом, вечера - чај; доручак - просена каша, ручак - пасуљ са месом и гриз, вечера - чај; доручак - просена каша, ручак - купус чорба (боршч), вечера - чај; доручак - просена каша, ручак - купус чорба (боршч) и кнедле са месом, вечера - чај; доручак - просена каша, ручак - просена супа, вечера - чај. Количина супе - 1.000-1.105 г, тежина главног јела - 300-329 г. Калоријска вредност - 1.298 КК; ручка - 1.422 КК; вечере (уз хлеб) - 500 КК. Али је ужина обично изостајала“. ${ }^{11}$ Према савременим препорукама Министарства здравља Русије мушкарци у узрасту од осамнаест до двадесет и девет година који се баве лаким физичким послом требало би да уносе 2.800 калорија. Нешто мање од тога могао је да добије дневно црвеноармејац у кухињи 4. гардијског механизованог корпуса који је био оштрица ударне снаге

9 ЦАМО РФ, 431 сп, д. 1, с. 1, „Журнал боевых действий 431 сп“.

10 Слуцкий Б., „Записки о войне“, О gруїих и о сеঠе, Москва, 2005, c. $28-32$.

11 ЦАМО РФ, 4 гвмк, ОО, д. 377, „Медицинские донесения корпусного врача“, с. 16. 
III украјинског фронта у јесен 1944. Овакво стање изазивало је забринутост и код санитетске контроле корпуса: „Квалитет припреме хране је низак, безукусан и без обавезне количине витаминизираних састојака. Калоријска вредност хране је недовољна... количина супе је велика због воде, а не хране, услед чега се губи укус јела... “ Занимљиво је да, на питање о томе колико су задовољни храном, војници нису изнели никакву критику осим једне девојке која је рекла: „Ових сплачина има довољно“.12 Повремено су чак и официри који су добијали повећану порцију били незадовољни не само квалитетом него и количином хране. ${ }^{13}$

Проблема је било и код снабдевености одећом и обућом. Након избијања рата 1941, уз велике губитке магацина и индустријских капацитета, с једне стране, и уз повећавање количине људства у војсци дошло је до несташица униформи и обуће. Бројне цивилне фабрике су кренуле у производњу војних униформи, што је повећало шаренило дезена и кројева. Војницима су давали униформу и из робних резерви које су чувале старе обрасце униформе РККА. Ратни плен је долазио у помоћ тамо где би затајила интендантска служба. Масовно су користили немачке каишеве (понекад чак нису ни скидали немачке ознаке са њих), а понекада су брусили средину да трофеј ослободе омрзнуте готике и кукастог крста. Чизме и шињели су такође спадали у тражене трофеје. Није било ни довољно ознака чинова и рода оружја као ни елементарних звездица, које су појединци секли од конзерви и качили на војничку капу згужвану кацигом. Није се радило само о мањку у магацинима или о неуредности већ и о својеврсном занемаривању личне имовине услед непредвидљивости ратне судбине.

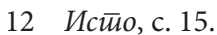

13 ЦАМО РФ, 52 сд, ПО, д. 105, с. 218; 233 сд, ПО, д. 93, с. 182. 
Ове уобичајене појаве у Црвеној армији биле су увелико раширене и у оним совјетским јединицама које су стигле на Балкан, па и у Србију. Обиље трофејне одеће уместо униформи, мањак обуће, доњег веша, мањак војничких торбица и ранчева, па се муниција носила у џеповима шињела, били су проблеми 233. пешадијске дивизије и у Украјини и у Молдавији а ситуација се није поправила ни на Балкану. ${ }^{14}$ Помоћна техничка опрема такође је била веома шарена. На пример, у корпусу генерала Жданова 65\% превозних неборбених механичких средстава су били заплењени аутомобили непријатеља. Уз достављена преко лендлиза возила ово је стварало велико шаренило па је у корпусу генерала Жданова било чак 97 врста превозних неборбених механичких средстава: татре и мерцедеси, опели и кубелвагени (будуће „бубе“), шевролети и студебекери, џемсији и немачки фордови. ${ }^{15}$ У јединицама је недостајало чак и обичног папира и машина за куцање те је значајан део штапских докумената па и поверљивих и строго поверљивих, куцан на полеђини немачких карата и образаца. ${ }^{16}$

Од тешких услова живота и стања сталног умора и борбеног стреса војници и официри нису могли да се лече одмором или релаксацијом, већ су користили алкохол као средство смирења душевних и физичких патњи. Осим борбене порције (100 мл вотке или 300 мл вина дневно), војници и официри су тежили да пронађу додатне изворе „течног заборава“. Пијанство се

14 ЦАМО РФ, 233 сд, ПО, д. 34-35; д. 93, 163-164, 213.

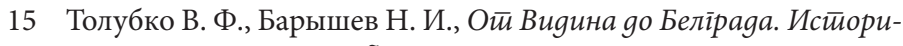
ко-мемуарный очерк о боевых gейстивиях советиских йанкистиов в Беліраgской оиерации, Под редакцией и с предисловием В. Ф. Чижа, Москва, 1968, с. 20.

16 Велики број докумената из фондова корпуса и дивизија III украјинског фронта у ЦАМО РФ. 
претворило у један од најчешћих и најблаже кажњаваних прекршаја. Проблем личног живота смртно уморних али ипак младих војника и официра, политичка управа Црвене армије је покушавала да реши насилним целибатом. Након уласка у веће градове команде корпуса и дивизија су играле улогу брижних родитеља забринутих за морал и чедност својих малолетних васпитаника и наређивале су „хитно затварање јавних кућа и забрану продаје алкохола“" ${ }^{17}$

Случајеви насиља, као и случајеви пљачке имовине и убијања оних који су покушавали да сачувају своју част или својину, спадали су у ред ретких, али ипак присутних појава. Мора се одмах констатовати да је војна команда предузимала велике напоре да спречи појаву криминалних девијација у редовима РККА. Совјетска врховна команда је била свесна да је „постојање појединих аморалних појава у војним јединицама као што су: пијанство и кавга, убијање цивила од стране наших војника, силовање жена, пљачка, - све ово оставља лош утисак на поједине слојеве друштва“, 18 и одлучно се са таквим појавама борила. Број кривичних дела које су починили црвеноармејци на подручју Србије и Југославије био је мањи од сличних појава у Мађарској и поготово у Немачкој. ${ }^{19}$ Оценити укупан број ових испада које су починили црвеноармејци на подручју Југославије је релативно тешко. Ипак у поверљивом извештају припремљеном за Тита уочи „нормализације“ односа са СССР-ом дате су одређене процене. Према овој анализи поједини официри и војници Црвене армије су починили на подручју ФНРЈ

17 ЦАМО РФ, 4 гвмК, ОО, д. 164, с. 642, 650.

18 ЦАМО РФ, ф. 57 А, д. 416, л. 138.

19 Ово признају и савремени руски истраживачи. Петров И., „Неммерсдорф: Между правдой и пропагандой“, Великая оболіанная война-2. Нам не за чйо каяйься!, Москва, 2008. 
низ кривичних дела: забележено је 1219 силовања, 359 покушаја силовања, 111 силовања са убиством, 248 силовања са покушајем убиства, 1204 пљачке са телесним повредама опљачканих. ${ }^{20}$ Међутим, и поред свих ових калкулација, овде се радило само о промилима, а не о процентима оних који су одскакали од многих хиљада поштених војника од којих су неки жртвовали свој живот да ослободе Србију од Немаца. Није случајно да је главна (иако не $100 \%$ делотворна) морална кочница за заустављање ових испада на тлу Југославије била осуда насилничког понашања (крађе, пљачке и насиља) од армијског колектива. Официри и војници су често пријављивали ово понашање својих несавесних другова, што није био случај у Мађарској и Аустрији. ${ }^{21}$

На формирање непосредних утисака који су се формирали код црвеноармијаца о Југославији и Србији ових погледа до доласка на подручје Југославије битно је утицала пропагандна активност политичких органа, која се испољавала кроз усмена предавања и војну штампу. ${ }^{22}$ Официри и они војници који су имали прилику да дођу до новина или да чују агитатора који је препричавао садржај војних новина, добијали су кратак приказ географије Југославије праћен набрајањем њених народа. Војне новине су такође наводиле улепшану биографију „рођеног војсковође“ - Јосипа Броза Тита. „Напредна и позитивна“ улога КПЈ

20 AJ, Arhiv J. B. Tita, Kabinet predsednika republike, I-3-a (SSSR), k. 170, Poseta državno-partijske delegacije SSSR-a na čelu sa N. S. Hruščovom 26. 5. - 3. 6. 1955, Informativno-politički materijal, 1.574.

21 Слуцкий Б., „Записки о войне“, О gруіих и о сеঠе, Москва, 2005, с. 101.

22 „Экономический и политический очерк. Югославия“, Звезgа Сo-

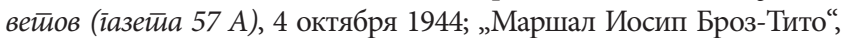
Звезяа Совейов (їазейа 57 A), 8 октября 1944; „Маршал Тито“, Вйереg за Роgину (їазетиа 233 gивизии), 3 октября 1944; „Народы-братья встретились", Звезgа Советиов (їазет̄а 57 A), 22 октября 1944. 
у започињању организованог партизанског рата супротстављана је описаном раду „народних издајника“ (Недића, Михаиловића, Павелића, Рупника). Основна идеја коју је читалац могао да добије из ових текстова била је та да су се у Југославији од самог почетка окупације, од 1941, партизани под командом Тита стално борили против Немаца и њихових савезника.

Друга веома битна идеја коју су желели да пренесу аутори информативно-пропагандних текстова био је опис „историјске улоге ослободилаца Руске армије и њене наследнице Црвене армије на Балкану“. Очито је да се овај мотив већ користио и пре уласка у Бугарску. Ипак, за разлику од Бугарске, у случају Југославије много већи значај је имала општа премиса тезе о ослобођењу - претерани опис патњи становништва под јармом Немаца и њихових савезника, омиљена пропагандна тема у приказима окупираних територија уопште. Овом општем пропагандном клишеу био је додат, веома популаран у другом делу рата, мотив братства словенских народа, чији је утицај био толики да је дошло чак до стварања посебне форме ословљавања множине припадника своје скупине. Наиме осим формалног „другови“ и колоквијалног „момци“у језику бораца се већ широко користила форма обраћања „Словени“ („Напред, Словени!“). У пропаганду се укључила и наука која је стварала „научно-популарне“ радове за „проширивање видика“ совјетског официра и пропагандисте у „словенском питању“. У више десетина хиљада примерака је био одштампан рад академика Н. Дежравина „Вековна борба Словена са немачким освајачима“. Србима је у том раду било посвећено читаво поглавље са јасним називом - „Бандитски напад аустријских Немаца на српски народ 1914 г. “23

23 Державин Н., Вековая борьба славян с немеикими захватичками, Москва, 1943, с. 76-81. 
Значај словенске заједнице припадници Црвене армије су могли да схвате већ након првих контаката са становништвом. У каснијим успоменама остало је забележено да је изазивала расположење и олакшање већ и сама чињеница да су натписи у Бугарској и Југославији били искључиво на руском војнику разумљивој ћирилици. За споразумевање са локалним становништвом није требао приручник за конверзацију. ${ }^{24}$ Уосталом, оваквих приручника у јединицама није ни било за разлику од широко присутних румунских, мађарских и немачких приручника за комуникацију. Чак су покушаји југословенске стране да користе у комуникацији преводиоце доживљавани код појединих црвеноармејаца као увреда и намерно отуђивање. ${ }^{25}$

Све ово је унапред стварало позитивну слику о Југославији (што је и иначе био циљ пропаганде) с тим да је ова стварана слика била „позитивнија“ него представа о околним народима. Очита је разлика и у интерном пропагандном материјалу (пажљиво скривена за време постојања Источног блока) и у препорукама политичког руководства о томе да треба разликовати пријатељске од непријатељских нација на путу Трећег украјинског фронта. У прве су спадали Југословени и Бугари, без изражене диференцијације у званичној пропаганди. У другу групу, чврсто дистанцирану мањком „пропагандне позитивности“, Мађари и Аустријанци, чије се „ослобођење од нацизма“ пропагандно декларисало, али је изгледало мање уверљиво у пракси због жилавог отпора који су они пружали. Негде између тих група били су Румуни као новостечени савезник, али без заборављања онога што су чинили за време румунске окупације у

24 Скоморохов Н. М., Боем живети истиребителел, Москва, 1975, с. 203.

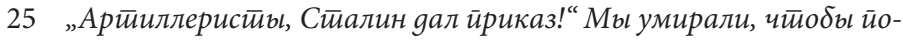
беgит̄ $ь$, Москва, 2006, с. 344. 
Украјини. ${ }^{26}$ У истом смеру иду и препоруке о јачању пажње и смањењу контаката са мађарским и немачким становништвом, које су политички одсеци дивизија и корпуса на препоруку надређених органа упућивали у штабове јединица у време напуштања југословенских предела. ${ }^{27}$ Већ на северу Војводине јединицама су чак биле упућене директне препоруке да се пази на национални састав цивилног становништва, јер трупе улазе на територију непријатељски расположене Мађарске. ${ }^{28}$

Објективни и мање објективни разлози су утицали на расположење совјетских војника према становништву Југославије. Према успоменама учесника рата, међу совјетским војницима и цивилима 1941-1943. постојао је драматичан осећај усамљености СССР-а у борби против Немаца и њихових савезника. Овај осећај узалуд је покушавала да сузбије званична совјетска пропаганда. Зато је онај ко се такође борио против Немаца од 1941. на сопственој територији, бранећи своје огњиште, природно стицао код совјетских војника позитиван имиџ.

Не можемо да оценимо колики је реално имала утицај пропаганда из 1941-1942. везана за устанак народа Југославије против окупатора - бројни написи у новинама и кратак играни филм „Ноћ над Београдом“ (1941). Доступност и утицај ових информација о борбама у Југославији тешко је утврдити, али је јасно да је њихово пласирање наилазило на низ препрека: мања доступност ове пропаганде за официре и војнике на ратишту (грађанске новине и биоскопске пројекције), општа шту-

26 Илустративани је приказ из политичког извештаја за официре пре уласка у Румунију. „Зверства румынских захватчиков, чувство ненависти и мести Красной армии к румынским оккупантам и наша политика по отношению к Румынии“. ЦАМО РФ, 233 сд, ПО, д. 91, с. 181.

27 ЦАМО РФ, 233 сд, ПО, д. 34, с. 162-165; д. 35, с. 283.

28 ЦАМО РФ, 233 сд, ПО, д. 34, с. 219. 
рост информација о Југославији и њихова затвореност у контекст бројних не баш истинитих описа устанака и диверзија „народних осветника“ у целој Европи. Мит о европском покрету отпора, као јакој и општенародној појави, пажљиво је градила совјетска пропаганда, што је умањивало ниво поверења или бар пажње читалаца ка појединачним догађајима. Најзад, међу масом црвеноармејаца 1941-1943. питања геополитике тешко да су могла да конкуришу решавању егзистенцијалних питања.

Ниво информисаности црвеноармејаца о Југословенима пре доласка РККА на Балкан сликовито илуструје дијалог који су у зиму 1943. водили српски заробљеник из мађарске радне чете и совјетски стражар. „Био је сунчан дан и мраз је попустио. Седео сам напољу поред зграде и сунчао се недалеко од млађег стражара. Упитао ме које сам националности кад натуцам руски. Одговорио сам му да сам 'Југославен'. По изразу његовог лица примећујем да не зна ко су Југословени. Поновиће он питање: 'Која је то националост?' Схватио сам да није чуо за Југославију, па сам допунио одговор: 'Серб!' Опет он не зна шта је то, а ја већ нервозно допуним: 'Балканец!' Е сад видим да не зна ни за тај део света на кугли земљиној и изнервиран рекох са осмехом: 'Фриц!' [йако су Руси колоквијално називале йоgанике Трећеī рајха - A. T.] 'А Фриц!' понови он и тако завршимо разговор. “29 Тим је било веће позитивно изненађење црвеноармејске масе која је наишла у Југославији на војнике са црвеним звездама на капама и сазнала од политичких пропагандиста да отпор ових бораца немачком окупатору није јењавао све од 1941.

Ипак, у односу према партизанима била је присустна и доза арогантности иначе типична за однос Црвене армије према партизанима и у самом СССР-у.

29 Paunić Ž., Sećanja na ratne dane 1941-1945, Novi Sad, 1997, str. 56. 
Овај елеменат био је базиран како на високом мишљењу о себи тако и на чињеници да партизани нису сматрани довољно дисциплинованим. ${ }^{30}$ Овај ироничан поглед на партизанске борце је фиксирао начелник војне јединице Црвене армије приликом гранатирања Трстеника. ${ }^{31}$ О позитивном, али и потцењивачком погледу сведочи и то да су на војним картама борбених операција и у борбеним плановима јединице НОВЈ веома често биле изостављене или су наведене на самом крају. Ипак, након првих борби дошло је до пораста поверења у војнике НОВЈ. Мржња партизана према Немцима није могла да не импонује војницима Црвене армије, иако се ова мржња понекад исказивала и превише, за укус совјетских официра, егзалтирано. Масовна и експресна стрељања заробљених немачких војника и њихових помагача (у које су партизани сврставали све политичке непријатеље) узалудно су покушавали да спрече представници политичких одсека совјетских јединица (не због хуманизма и свести о правима заробљеника, већ због могућег негативног утицаја на спремност непријатеља да се преда). Појавило се више опомена и забрана изручења заробљеника партизанским јединицама. Због ових немилих појава се препоручивало да се заробљеници упућују у сабирне центре у позадину. ${ }^{32}$ Било је и случајева који су изазивали још већу критику совјетских политичких органа (али и неформалну симпатију црвеноармејаца). На пример у Панчеву када је

30 'Создават̄в невыносимые условия gля враїа и всех еі̄о йособников...' Красные ӣарӣизаны Украины, 1941-1944: малоизученные стираницы истиорииб Киев, 2006.

31 Када су видели резултат артиљеријског плотуна, „југословенски партизани су се обрадовали као деца - скакали су, викали

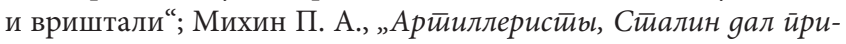

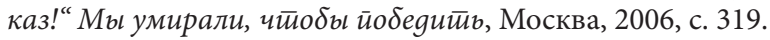

32 Слуцкий Б., „Записки о войне“, О gруіих и о себе, Москва, 2005, c. 62-65. 
након пар дана после уласка партизана у град освануо плакат: „'Немачки становници града Панчева су отровали вином девет војника Црвене армије. Као одговор на то стрељано је двеста и педесет Немаца - становника Панчева'... Даље се наводио списак стрељаних, који је започињао са председником Културбунда, градоначелником, бившим есесовцима итд. Једанаести на списку је био Грос - кафеџија. Његово презиме је пратила лаконска опаска - 'велики фашиста', па још шеснаест немачких презимена са исто толико лаконским карактеристикама. И најзад још двеста двадесет и три Немца за које је речено само то да су они становници града Панчева. На крају је стајало: 'Упозоравамо све Немце, да ће надаље за сваког отрованог црвеноармејца или партизана бити стрељано не тридесет, већ сто људи'““33

После краћег времена дошло је и до неформалног зближавања између црвеноармејаца и партизана, које се понекад претварало у колективне пијанке. Ово испољавање осећања блискости у виду колективних пијанки се појављивало и касније када су совјетски војници добијали прилику да дођу у друштво војника НОВЈ. ${ }^{34}$ Таква „дружења“ су изазивала оштру реакцију политичких органа совјетских јединица. ${ }^{35}$ Командант 57. армије морао је да објави посебну наредбу № BC/0497, 5. децембра 1944. „О појавама контаката између војника дивизија са локалним становништвом Југославије и о категоричној забрани било каквих личних контаката припадника армије са становништвом Румуније и Југославије“. ${ }^{36}$

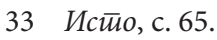

34 ЦАМО РФ, 4 гвмк, ОО, д. 164, с. 716; Чхеидзе А. А., Зайиски gунайскоі̄o развеgчика, Москва, 1984, стр. 89; Краснофлотец Пахомов Игорь Николаевич, http://www.iremember.ru/content/ view/448/23/lang,ru/.

35 ЦАМО РФ, 233 сд, ПО, д. 35, с. 283.

36 ЦАМО РФ, 233 сд, ПО, д. 140, с. 203. 
Готово сви совјетски учесници у борбама у Југославији сећали су се гостопримљивог односа становништва, што је доприносило стварању позитивног утиска о Југословенима и о Југославији. Однос припадника Црвене армије према цивилном становништву Југославије био је базиран на топлој добродошлици приређиваној совјетским војницима у сваком насељу. Сусрет са новом средином наметао је природно упоређивање стандарда живота локалног сеоског становништва са животом у СССР-у. Иако је у Србији овај стандард био углавном виши то није изазивало мржњу и завист као на богатим поседима у Румунији, где је стандард био наивно тумачен „ратним бенефицијама“. ${ }^{37}$ Ситуација у Србији није личила ни на сиромаштво румунских сељака које је одскакало од луксуза „ескплоататорске“ класе и служило је као добра илустрација за идеолошпку конструкцију о „неправдама класног друштва“. Стање у Србији војнике је углавном подсећало на године совјетске нове економске йолийике 1921-1928. (НЕП) када је слободно предузетништво омогућило сељацима да повисе свој животни стандард: „за неколико сати боравка у кући стигао сам да ручам и о много чему да поразговарам са сељацима. Све је код њих било тако како је било код нас у годинама НЕП-а: није богат живот, али је са надом на побољшање. И бриге сељачке су биле исте као код мог оца 1924-1925“38 Паметнији су задржавали ова нова запажања за себе. Онај ко је то јавно рекао био је кажњаван, попут наредника Нонца, који је изјавио саборцима: „Наши се колхози нису доказали. Самостално домаћинство је много боље него колхозно. Колхозници у нашој земљи живе лоше“, што је СМЕРШ карактерисао као „антисовјетску агитацију“.39

37 Милуновић М., Og немила gо неgраїа, Београд, 1992, с. 52-55.

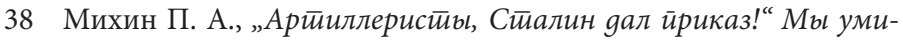
рали, чйобы йобеgитйь, Москва, 2006, с. 292, 313.

39 ЦАМО РФ, 233 сд, ПО, д. 93, с. 182. 
Позитиван однос према Југославији види се и из мемоара совјетских учесника борби у Југославији, где се могу наћи одушевљени описи југословенске природе (појава иначе нетипична за совјетске ратне успомене). „Било је рано јутро. Октобар у Југославији је као крај августа код нас: то још није јесен већ свуда обилно зеленило, цвеће, топло и сунчано... Свуда мирише природа. Лепота невиђена! Провидан ваздух, натопљен аромама дрвећа, цвећа и трава са сваким уздахом се разлива по телу. 'Ево живи народ као у рају.“440 Или „Какви су називи - благозвучни и сочни! Две трећине земље заузимају планине. И то какве планине! Не можеш њима да се надивиш. Са висина на којима смо летели, оне су уопште неописиве - то мораш само да видиш“" ${ }^{11}$

Анализирајући перцепцију војника Црвене армије, не може се прецизно утврдити да ли су они разликовали Југословене и Србе, и да ли је било неке разлике у перцепцији појединих југословенских народа. Први закључак на основу објављених мемоара и архивске грађе пре би био да нису него позитиван. Помена Срба малтене нема и увек се користило збирно име Југословени. Међутим, веома је вероватно да је неких неформалних назнака ове диференцијације ипак било. Дочек Црвене армије у Србији, где чак ни наводни (ЈВуО) ни реални сарадници (СДК) окупатора нису хтели да се боре против Црвене армије, није могао да не одудара од односа према црвеноармејцима у Хрватској, где су се хрватске јединице здружено бориле, раме уз раме са Немцима, у одбрани своје домовине од „црвене хорде“. Занимљиво је да у поменутом роману Маљцева има позитивних ликова из свих народа Југославије, али је

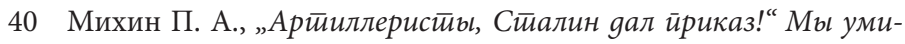
рали, чйобы йобеgит̄иь, Москва, 2006, с. 300.

41 Скоморохов Н. М., Боем живети исииребииельь, Москва, 1975, с. 201. 
већина измишљених ликова негативаца хрватског порекла, што индиректно сведочи о преокрету у односу на коминтерновске стереотипе. Није могло да не дође до повратне реакције и на посебно „српско и православно русофилство“ цивилног српског станвништва, које су уочавали припадници политичког апарата Црвене армије у Југославији. ${ }^{42}$

У овом тексту као сликовит пример борбе црвеноармејаца за српски град одабрали смо пример града Крушевца. Крушевац је вероватно највећи град у Сpбији који су 1944. године борци ЈВуО под командом пуковника Драгутина Кесеровића ослободили од Немаца. У интерним документима и званичним публикацијама страна везаних за борбе око Крушевца може да се пронађе неколико верзија овог ослобођења. Ево на пример, шта се каже о томе у заједничкој совјетско-југословенској монографији: „јединице 64. стрељачког корпуса Црвене армије и 2. пролетерске дивизије НОВЈ после заузећа Крушевца су успешно напредовале на запад“. 43 Постоји и чисто партизанска верзија о ослобођењу Крушевца, које је извела Четврта пролетерска (црногорска) бригада. ${ }^{44}$ Постоји и извештај самог Кесеровића о догађајима код Крушевца у коме он тврди да су Крушевац ослободили борци ЈВуО. ${ }^{45}$ Све ово може да се допуни на основу белешке америчког поручника Елсфорта Крамера, представника OSS-а који се спремао да постави изнад ослобођеног Крушевца америчку

42 Слуцкий Б., „Записки о войне“, О gруїих и о сеঠе, Москва, 2005, c. 64-74.

43 Беліраяская оиеерачия, Москва, 1964, с. 262.

44 О партизанском „ослобођењу“ Крушевца видети: Крушевац: ослобођени іраg, Крушевац, 1966; Јанковић Б., Чейврита ирролеиерска ирноіорска бриїаgа, Београд, 1975.

45 Зборник НОР-а, т. XIV, књ. 4, Београд, 1985, с. 869-882. 
заставу. ${ }^{46}$ Најзад постоји низ докумената, недавно отворених за истраживаче у архиви Министарства одбране Русије, која допуњују саопштење Кесеровића, а уједно пружају могућност да се сагледају извори „партизанске“ верзије догађаја.

Укратко, ситуација у Крушевцу према совјетским и четничким подацима била је следећа. На ултиматум Д. Кесеровића поднет 13. октобра немачком команданту Крушевца, долази до капитулације Немаца у овом граду 14. октобра. У Кесеровићевом штабу у то доба је био амерички поручник Елсворт Крамер. У преговорима Кесеровића (који се чак представио као посредник америчког официра) са немачким командантом као основни стимулативни мотив за капитулацију је наведена могућност да се Крушевац преда америчкој, а не совјетској војсци и на тај начин дође до спречавања уласка у град Црвене армије и партизана. Према наводима у извештају Крамера преговори са Немцима су почели већ 22. септембра али тада нису уродили плодом. ${ }^{47}$ Тек по доласку совјетских трупа у непосредну близину Немци су се заинтересовали за овај предлог и у Крушевац је мањим авионом „шторх“ (Fi.156) био упућен пуковник немачког генералног штаба начелник штаба корпуса „Милер“ Бернгард фон дер Шевалери, који је стигао 14. октобра и био заробљен од припадника ЈВуО. Касније у совјетском заробљеништву Шевалери је изјавио да „се није плашио насиља од стране четнике, јер су они свуда радили у контакту са Немцима““48 У Крушев-

46 Објављен је извештај поручника Крамера. Pavlović M., „Očevidac Građanskog rata u Srbiji“, Istorija 20. veka, 1/2007.

47 NARA, Declassified: NND 877092 by AB 12/30/2004. Orders to Lt. Col. Robert H. McDowell, AUS from Edward J. Green, Lt. Comdr., USNR. Headquarters company B, 2677th Regiment, Office of strategic services (Prov), APO 534, U. S. Army. 15 August 1944.

48 ЦАМО РФ, 68 ск, РО, д. 242, „Допрос военнопленного начальника штаба корпуса 'Мюллер' полковника нештаба Бернгарда фон дер Шевалери“, с. 268. 
цу је дошло до сусрета Шевалерија са Крамером, који је објаснио да је последњи циљ - „заузети са одредима четника низ насеља“ где ће бити подигнута америчка застава и на тај начин спречен улазак јединица Црвене армије у ова насеља“" 49

У исто време, 13. октобра 1944, поручник Крамер је написао писмо команданту наступајуће 52. стрељачке дивизије генералу Л. М. Миљајеву у коме је „изложио да жели да се састане са њим и молио га да му се обезбеди пут до њега“. Ово писмо је било упућено „када се сазнало за прелазак руских трупа преко реке В. Мораве“ (вероватно се радило о преласку 16. самосталног јуришног батаљона код Варварина). Писмо је понео потпоручник ЈВуО Александар Златковић који је кренуо 13. октобра у 18.00 а доставио писмо 14. октобра у 10.00 сати. Миљајев је одмах поставио питање да ли ће се четници борити против снага његове дивизије. Изненађени Златковић је изјавио да је то немогуће јер су РККА и ЈВуО савезници. На то је Миљајев изричито рекао: „Не, ми нисмо савезници“. Осим тога генерал Миљајев је додао да би јединице ЈВуО морале да истога дана (14. октобра) до шеснаест сати разоружају Немце и да потом положе и своје и немачко оружје трупама Црвене армије..$^{50}$ Очито је се да Миљајев овде придржавао инструкција добијених преко политичког и обавештајног одсека дивизија и корпуса 57. армије пре уласка у Србију. Информација обавештајног одсека од 5. септембра 1944. дефинисала је „четнике Драже Михаиловића“ као „реакционарну војску... која се бори на страни окупатора од 1941“ и „има их око три-

49 ЦАМО РФ, 68 ск, РО, д. 242, „Допрос военнопленного начальника штаба корпуса 'Мюллер' полковника нештаба Бернгарда фон дер Шевалери“, с. 265.

50 Зборник НОР-a, т. XIV, књ. 4, Београд, 1985, с. 869-882. 
десет хиљада, с тим да је већина смештена у Србији и Санџаку (двадесет хиљада бораца)“.51

Још пре доласка потпоручника Златковића генерал Миљајев је упутио наредбу својим јединицама (429, 431, и 439. пуку, ојачаним јединицама самоходне и антитенковске артиљерије) да крену према Крушевцу. ${ }^{52}$ У борбеном наређењу бр. 35, које су пукови примили 13. октобра у 24.00, Миљајев је прецизирао главни положај. Према њему, дивизија је пратећи противника у повлачењу на северозапад и запад заузела 13. октобра у 13.00 Параћин и заузела положај Стрижа, Доње Видово, Сталаћ, Ћићевац. Следећег дана (14. октобра) био је планиран наставак офанзиве и заузимање Крушевца. Дивизија се налазила на крајњем левом крилу совјетских јединица и није имала с леве стране означене совјетске или савезничке трупе, а с десне стране наступале су јединице 68. стрељачког корпуса. Главни задатак за дивизију био је да до четрнаест часова заузме град Крушевац и пређе на другу страну Мораве. Генерал Миљајев је поделио своје снаге. Заузето подручје: Параћин, Доње Видово, Горин, Сикирица, Дреновац требало је да чува 429. стрељачки пук до доласка јединица 233. стрељачке дивизије. Он је био појачан 523. минобацачким пуком и два дивизиона 1028. артиљеријског пука. На тај начин значајан део артиљерије Миљајев је оставио да брани већ освојен положај, што је било оправдано у одсуству левог крила одбране и у време убрзаног повлачења непријатеља када је темпо напредовања био битнији од

51 ЦАМО РФ, 68 ск, РО, д. 242, с. 270-281. „Справка о составе и дислокации Югославской армии, немецких войск на Балканах на 19 сентября 1944 г. и реакционных войск Павелича, Недича, Михайловича и Рупника на 5 сентября 1944.“

52 ЦАМО РФ, 431 сп, д. 3, с. 116, „Боевой приказ № 35. штадива 52. 24.00 13. 10. $44^{“}$. 
ватрене снаге предњих јединица. По доласку јединица 233. дивизије, 429. пук са снагама појачања придружио би се снагама дивизија, које је у то доба већ требало да буду у Крушевцу. Командно место је требало да буде у Сикирици. Заузимање Ћићевца и Сталаћа до девет часова је било задатак 431. стрељачког пука уз помоћ Сaмосталног гардијског самоходног артиљеријског пука и са дивизионом 1028. артиљеријског пука. Након тога командно место 431. пука, један батаљон 431. пука и топови су морали да се задрже у Ћићевцу, а два батаљона пешадије и „самохотки“ требало је да до четрнаест сати са севера и истока уђу у Крушевац и да са задрже у северном делу града. Најзад 439. стрељачки пук појачан 418. антитенковским артиљеријским пуком је требало да обиђе Мојсињску планину са истока и да уђе у Крушевац преко Прасковче и Гаглова са истока и југозапада и да заузме јужни део града Крушевца. Сама команда 52. дивизије се 13. октобра налазила у Стрижи, а следећег дана, 14. октобра, по заузимању Ћићевца, било је планирано да се она пребаци у њега. Задатак да први уђе у Крушевац је добио 16. самостални јуришни батаљон III украјинског фронта који је морао кренути из Варварина према Крушевцу већ у девет часова 14. октобра, ући у град са северозапада (од Јасике) и заузети северозападни део града. Припрема наступања је била поверена извиђачким водовима који је требало да крену испред својих јединица већ у ноћи 13. на 14. октобар.

Овај извештај нам помаже да појаснимо ситуацију у којој је пуковник Кесеровић упутио свог делегата код генерала Миљајева. Наиме, може се уочити да је у том тренутку идеја о преговорима већ била закаснела. Преговори су започети када је дивизија већ увелико била у току извршења борбеног задатка. У време када је потпоручник Златковић почео да износи планове Кесеровића у вези са предајом Крушевца „самохотке“ 
ИСУ-122 из Самосталног гардијског самоходног артиљеријског пука већ су се налазиле у зони гађања Крушевца. ${ }^{53}$ При том ове „самохотке“ у тренутку преговора нису стајале већ су напредовале према Крушевцу, као и други делови 52. дивизије и јединица појачања. У овим околностима другачије звучи одговор Миљајева да предаја јединица Кесеровића у Крушевцу има смисла само до шеснаест часова. Овде се није радило, као што је касније оценио Кесеровић, о намерној жељи да се поставе неизводљиви услови, већ о томе да су пукови, дивизије, корпуси и армије имали унапред предвиђене рокове офанзиве. Оперативна дисциплина је диктирала паралелност кретања јединица у офанзиви. Да заустави развој офанзиве III украјинског фронта због преговора са потпоручником ЈВуО А. Златковићем, генерал-мајор Миљајев није могао, а вероватно није ни хтео.

У самом Крушевцу ситуација се развијала својим током. Према извештају Кесеровића, већ у 6.30 у његов штаб је стигао мајор Весић заједно са „једним руским поручником“. С обзиром на то да се касније тај совјетски поручник ослањао на јединице које су наступале из правца Јасике, може се претпоставити да се радило о извиђачком воду 16. самосталног јуришног батаљона.

Потребно је објаснити шта је био 16. самостални јуришни батаљон III украјинског фронта. Овај китњаст назив је крио посебну - казнену официрску јединицу. Иначе РККА је већ 1942. наређењем Стаљина бр. 227 од 28. јула 1942. позајмио из Вермахта једну од идеја „масовног рата“ - казнене јединице. ${ }^{54}$ Јуришни батаљони

53 ИСУ-122 је био наоружан топовима А-19С калибра 121,92 мм (директно гађање 5 км а хаубично 14,3 км) тежина једног пуњења - 25 кг. Карпенко А. В., „Тяжелые САУ“, Танкомастере, № 4, 2001.

54 Колбасов, Н. К., Толстой, И. А., Ширрафники. Люgи в кирасах, Москва 1990; Рубцов Ю. В., Шитрафники Великой Оиечестивенной, Москва, 2007. 
имали су сличну улогу, иако је назив „казнени“ био намерно изостављен. Јуришни батаљони су створени на основу Стаљиновог наређења бр. Орг-2-1348 од 1. августа $1943 . .^{55}$ У њима су само командир батаљона, његов заменик за кадровска питања, начелник штаба и команданти чета били из сталног официрског састава. Сви остали су били из „специјалног официрског контингента“. То су били официри који су се за време немачке офанзиве 1941-1942. нашли на окупираној територији и нису се придружили партизанским јединицама нити су покушали да се пробију до активне армије, већ су се притајили и у „породичном амбијенту“ дочекали долазак совјетских трупа. Формално нису били осуђивани и након филтрације коју је обавио НКВД, већина њих је долазила на официрска места у обичне јединице. Пре тога морали су током два месеца да врате држави дуг који су њихове савесније колеге давале док су они „паметно ишчекивали“. За време службе у јуришним батаљонима носили су привремену ознаку звања, али им је то време рачунато у рок официрске службе, а њихове породице су добијале примања одговарајућа њиховом звању. По истеку два месеца проведена у борби или пре тог рока у случају рањавања или добијања ордена, припадници јуришног корпуса су распоређивани у обичне јединице РККА према својој војној струци и звању. ${ }^{56} \mathrm{Jy}-$ ришни батаљони су сматрани посебно подесним јединицама за први улазак у мање непријатељске градове.

На тај начин и командир извиђачког вода 16. јуришног батаљона који је стигао код мајора Весића, а после у његовој пратњи и код пуковника Кесеровића, такође је припадао групи специјалног официрског

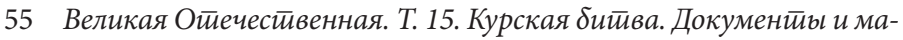

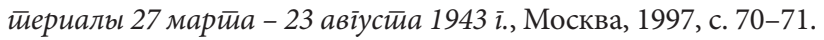

56 Великая Оиечестивенная. T.15. Курская битива. Докуменйы и ма-

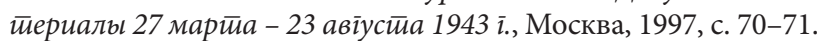


контингента. Према Кесеровићу, совјетски лајтнант је рекао да „има овлаштење да регулише односе између наших трупа и Руских трупа које надиру према Крушевцу. Рекао је да ћу ја остати као командант у Крушевцу да се наше трупе третирају као савезничке, да се партизанима не дозвољава долазак у Крушевац и да ће ако покушају да нас нападну бити разоружани“. Овај савезнички однос према четничким јединицама су испољавали према изјави мајора Весића и други припадници 16. јуришног батаљона који су хитали према Крушевцу. Осокољени Кесеровић поверовао је да је у центру савезничке пажње јер се нашао у друштву америчког и совјетског поручника. Кесеровић је добио извештај о напредовању совјетских јединица из правца Јасике и одлучио да убрза преговоре са Немцима и да им постави ултиматум. Већ у осам часова 14. октобра код њега су стигли оберфирер Кум и мајор Кни који су разговарали са њим о предаји. Мајор Кни, командант Крушевца, према наводима Е. Крамера, био је изненађен и „питао зашто га четници нису бранили, а Кесеровић је одговорио да му је обећао само да ће се борити против партизана и комуниста али не и Руса јер су они савезници“. ${ }^{57}$ После ових преговора, уз обећање о предаји, немачки официри су слободно отпутовали назад.

Овај пут изненађење је очекивало Кесеровића јер само је део Немаца одлучио да испуни своје обећање и да се преда. Јединице 7. СС дивизије „Принц Еуген“ радио-станицом су позвале тенкове и уз њихову помоћ се повукли према Краљеву. Према Кесеровићу мало ко од Немаца се извукао. ${ }^{58}$ Командант 7. СС дивизије О. Кум се не сећа „кобног по Немце повлачења“ из Крушевца

57 Pavlović M., „Očevidac Građanskog rata u Srbiji“, Istorija 20. veka, 1/2007, str. 179.

58 Зборник НОР-а, т. XIV, књ. 4, Београд, 1985, с. 869-882. 
у својим веома детаљним успоменама. ${ }^{59}$ Други учесник догађаја на страни ЈВуО навео је да су се Немци организовано повлачили од Сталаћа (где су стигли совјетске јединице) и да су тенкови, оклопна возила и камиони са војницима „пројурили без задржавања кроз град и ослободили своје војнике“ без посебних сметњи „јер се на тенкове није могло јуришати с голим рукама“" ${ }^{60}$ Не може пак да се порекне да су из немачких магацина били су узети богати ратни трофеји. Осим тога борци ЈВуО су успели да заробе део војника Вермахта и Руског заштитног корпуса који су били стационирани у Крушевцу.

После повлачења возила и људства 7. дивизије СС „Принц Еуген“ центар Крушевца је био окићен југословенским, америчким, енглеским и совјетским заставама, а грађанство је формирало и одбор за дочек. У међувремену у град је стигао 16. јуришни батаљон. Командант батаљона потпуковник Проњин стигао је на челу свог батаљона који се махом кретао пешке, али је имао и неколико коњских запрега са батеријом мањих (45 мм) противтенковских топова, одељењем минобацача и одељењем противоклопних пушака. Потпуковник који је очекивао љуту борбу, а уместо тога добио свечани дочек, био је одушевљен. Његов говор донекле открива и оно што је рекао поручник из његовог извиђачког вода. Потпуковник Проњин је, према наводу Кесеровића, рекао да су „му познате наше борбе од 1941. год, да се наша војска треба сматрати као регуларна, а да ће се партизани разоружати „Кесеровић, Крамер и Проњин су се обратили грађанима са балкона хотела „Париз“.61

59 Kumm O., Vorwärts Prinz Eugen! Geschichte der 7.SS-Freiwilligen Gebirgs Division „Prinz Eugen“, Dresden, 2007.

60 Младеновић М., Лажни ияоли и варљиви ияеали, Београд, 2004, c. 346.

61 Pavlović M., „Očevidac Građanskog rata u Srbiji“, Istorija 20. veka, 1/2007, str. 179. Постоји и фотографија овог наступа. Самарџић М.,

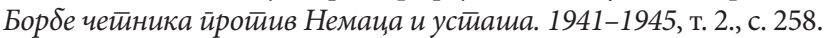


Уз сагледавање свих околности јасно је да се радило о евидентном неспоразуму и забуни код пуковника Проњина. Речи потпуковника Проњина о борбама од 1941. сведоче о томе да су официри 16. јуришног батаљона сматрали да имају посла са Титовим борцима, а не са четницима. О борбама четника против Немаца 1941. потпуковник Проњин и његови војници нису могли да знају јер је о четницима совјетска пропаганда говорила веома мало, чак и у лето 1941. С друге стране, Проњин је сигурно имао прилику да чита у армијским новинама чланак о „НОВЈ и партизанима“ и о томе да су се они борили против Немаца од 1941. ${ }^{62}$ Мора да се узме у обзир и то да су Проњин и његов батаљон стигли на фронт тек 10. октобра 1944, а први пут учествовали у судару са непријатељем у борби за Параћин 13. октобра. ${ }^{63}$

Због тога је о препорученом негативном погледу на ЈВуО Проњин могао бити необавештен. Ако су Кесеровић и Весић избегли назив „четници“ и представили се као регуларна „Југословенска војска у отаџбини“, није било тешко да се они помешају са другом „Народноослободилачком војском Југославије, како су се у то доба већ давно називали партизани. Посебно обећавајуће могле су да изгледају за Кесеровића речи Проњина „да је регуларна војска - нешто добро, а партизани - нешто лоше“. У томе нема ништа контрадикторно за једног совјетског официра, јер у перцепцији регуларне совјетске војске не само „партизанштина“ већ и „партизани“ (не своји него и инострани) су били сумњиви. ${ }^{64}$ Улогу у

62 „Югославия. Экономический и политический очерк.“, Звезgа Советиов (Армейская їазетиа 57 A), 4 октября 1944.

63 ЦАМО РФ, 52 сд, ПО, д. 51, „Боевые отзывы“, с. 1-2.

64 Разлози томе су били у варијацијама дисциплине и понашања код партизана. „Созgаватиь невыносимые условия gля враїа и всех еі̄о йособников..." Красные йарйизаны Украины, 19411944: малоизученные стираницы истиории. Киев, 2006. 
овоме су сигурно одиграле и информације које је потпуковник Проњин добио од генерала Миљајева. Према изјави потпоручника Златковића, генерал Миљајев је показао на карти да су свуда око Крушевца титовци. ${ }^{65}$

Осим уопштених разговора са Проњином, Кесеровић је покушао да сазна и то да ли има још неких совјетских трупа које напредују према Крушевцу. На директно питање, добио је негативан одговор. То што је Кесеровић био изненађен тиме што један официр Црвене армије није пожурио да саопшти борбени распоред дивизије (најповерљивији податак који је вероватно могао да зна официр нивоа команданта батаљона) човеку кога је видио први пут у животу сведочи не о „подмуклости“ Проњина, како је тумачио Кесеровић, већ и о схватању појма „војничка тајна“ самог Кесеровића. Када су касније из правца Дедине, око тринаест сати, стигле совјетски „самохотке“ и два батаљона 431. пука Кесеровић је опет био изненађен. Заједно са овим другим таласом совјетских трупа у Крушевац су ушли и партизани.

Ситуација је постала изненађујућа и за совјетску страну. Пилетић је кренуо у сусрет Миљајеву, који је кренуо њему у сусрет и није се задржао у Ћићевцу као што је било планирано. Када је Миљајев схватио да је дошло до борбене сарадње коју нису предвиделе наредбе Политичког одсека 57. армије, постао је „изузетно хладан и надут и није хтео ни да пружи руку помоћнику Кесеровића“. Припадници пратеће јединице су наглас коментарисали монархистичке амблеме на униформи пратилаца Кесеровића. ${ }^{66}$ До сусрета Миљајева и Кесеровића је дошло између Јасике и Крушевца, и након упознавања, они су се вратили у Крушевац и отишли у хотел „Париз“. Тамо је Миљајев срео и америчког поручника Кра-

65 Зборник НОР-а, т. XIV, књ. 4, Београд, 1985, с. 869-882.

66 Зборник НОР-а, т. XIV, књ. 4, Београд, 1985, с. 869-882. 
мера. Генерал Миљајев је изразио сумњу у овлашћења и идентитет поручника Крамера, па је наредио да се до даљњег Крамер ухапси. ${ }^{67}$ Према Крамеровим сећањима, следећег дана (15. октобра) генерал Хол из америчке мисије у Софији је био информисан о овом догађају, али тек 17. октобра, након низа испитивања, Совјети су предали Крамера генералу Холу. ${ }^{68}$ Кесеровић, коме је све већ било јасно, повукао се у тоалет, споредним излазом напустио хотел и отишао у свој штаб, који се ускоро (до шеснаест сати тог 14. октобра) повукао из града. ${ }^{69}$

На помолу је била једна неочекивана трагедија. Уз јалове преговоре између Миљајева и Кесеровићевих представника, припадници Црвене армије и партизани су разоружавали и хапсили припаднике ЈВуО, који су још пре неколико сати мислили да је дошло до дугоочекиваног сусрета са савезницима. Неколико десетина четника је било ухапшено, пребијено и опљачкано. Иако Кесеровић пише да је предаја била поносна и мирна, дошло је и до борби између несуђених савезника. ${ }^{70}$ Ову борбу у вечерњим сатима описао је и други учесник догађаја $\mathrm{M}$. Младеновић који је тврдио да се „само што пао мрак чула борба по периферији града“. „Борба у Крушевцу и по периферији трајала је целе ноћи са највећом жестином. Руси и партизани овладали су Крушевцем."

67 У записнику о саслушању Фон Шевалериа пише „четници предали пуковника, његовог пилота и америчког официра на располагање команди Црвене армије“. Совјети су предали Крамера генералу Холу. ЦАМО РФ, 68 ск, РО, д. 242, „Допрос военнопленного начальника штаба корпуса 'Мюллер' полковника нештаба Бернгарда фон дер Шевалери“.

68 Pavlović M., „Očevidac Građanskog rata u Srbiji“, Istorija 20. veka, $1 / 2007$.

69 Зборник НОР-а, т. XIV, књ. 4, Београд, 1985, с. 869-882.

70 ЦАМО РФ, 52 сд, ПО, д. 48, „Боевые донесения“, с. 67-70.

71 Младеновић М., Лажни ияоли и варљиви ияеали, Београд, 2004, c. $347-350$. 
Тешко је утврдити губитке бораца ЈВуО и регуларних јединица 52. дивизије (ако је тих губитака и било), али на основу тачних извештаја из 16 . јуришног батаљона може се закључити да је у њему било дванаест рањеника од којих је један тешко рањени био евакуисан. ${ }^{72}$ Немачко оружје, које су заробили припадници ЈВуО, било је подељено партизанима, а предат је и део заробљеника који су били одмах ликвидирани. ${ }^{73}$ Ово је било урађено упркос постојећим наредбама да се оружје шаље трофејним јединицама РККА, а да се заробљеници шаљу у позадину и да се тамо уз записник предају посебно одређеним представницима нове југословенске власти. ${ }^{74}$ Крвави обрачун партизана са „народним непријатељима“ забележио је не само М. Младеновић већ и интерна совјетска војна документа. Трагедија се одигравала све до 17. октобра када су се преостали борци ЈВуО повукли у планине, а совјетске и партизанске трупе кренуле према Краљеву.

Околности борбе за Београд су више него познати. Борбе за Београд представљали су круну Београдске операције, која се завршила ослобађањем од Немаца главног града Југославије снагама Црвене армије и НОВЈ. По завршетку ослобођења било је места за жалбе и притужбе руководства КПЈ, појединости аморалних испада црвеноармејаца, а осим тога и на још једну појаву - однос према партизанима и НОВЈ као савезнику. Југословенско руководство је неколико пута молило да се израз „ослобођење Београда снагама Црвене армије“ замени са формулацијом „ослобођење Београда

72 ЦАМО РФ, 16 ошсб сд, Алфавитная книга офицерского состава, п. 165, 260, 741, 744, 749, 897, 921, 926, 934, 946, 947, 950, 974.

73 Младеновић М., Лажни ияоли и варљиви ияеали, Београд, 2004, c. $347-350$.

74 ЦАМО РФ, 52 сд, ПО, д. 36, „Политические донесения“, с. 61-62. 
снагама Црвене армије и југословенским трупама“, да се заведе војнички поздрав југословенским официрима, да се заустави однос према југословенској војсци „као неспособној и другоразредној“.75 Према искуству и објашњењу југословенских пропагандиста и процени њихових совјетских колега ово је било изузетно битно, јер грађански Београд „веома често је спајао и супротстављао своје русофилство са антититоизмом, спрдао се његовој сиромашној војсци, и понекад је и отворено демонстрирао одговарајуће осећаје“ ${ }^{46}$ Осим „мрља на Сунцу“, совјетског животног стандарда и морала, препотентности појединих официра, југословенски комунисти су доживели непријатна искуства и када је био изневерен њихов осећај присног заједништва и чак поистовећивања са СССР-ом. У непосредном додиру са совјетским војницима и официрима III украјинског фронта припадници КПЈ у веома брзо осетили да их чланови ВКП(б) пак увелико сматрају комунистима друге сорте. КПЈ, као и друге стране комунистичке партије према мишљењу совјетских функционера, била је само „творевина“ и „еманација“ ВКП(б), што су се они и трудили да ставе до знања већ у првом контакту. ${ }^{77}$ Искуство хладнијег него што се очекивало совјетског пријема су забележили скоро сви мемоаристи који су имали прилику да се по први пут сретну са совјетским војницима и официрма. Ипак, било би потпуно неправилно тврдити да је укупна југословенска и пре свега српска перцепција совјетских војника у Београду била само негативна. Дугоочекивано ослобођење и сусрети са „Русима“ нису могли да буду потпуно помућени испадима појединаца и надувено хладним и опрезним

75 Слуцкий Б., „Записки о войне“, O gруїих и о сеঠе, Москва, 2005, с. 75.

76 Истио

77 Исйо, с. 74. 
држањем совјетских официра. Совјетска материјална и војна помоћ НОВЈ, помоћ коју је пружала совјетска држава у завршном раздобљу рата, такође је утицала на стварање позитивније слике о СССР-у иако ни то није било без понеких забуна и неспоразума. ${ }^{78}$

Комбинација од среће да се Немцима „виде леђа“, помешаности позитивних емоција према Русима и непознавања карактера комунистичких режима водила је дирљивим сценама. Ево како је описао одлазак Немаца и долазак Црвене армије Јуриј Лобачев у својим мемоарима. ${ }^{79}$ Уз надареност сликара и писаца и добро памћење, Лобачев је дао приказ једног од првих тренутака доласка „црвених Руса“ у Београд: „Сву ноћ су пролазиле, журећи према центру града, колоне Немаца, четника. И настала је нека чудна, необична тишина. Свиће. Пукла је зора тог петка, 15. октобра 1944. године. Свежег, прозрачног, јесењег дана. Но, ето, на крају данашње улице Максима Горког, дуж зидова порушене куће, са пушком на готовс, појавила се силуета, за њом друга, трећа. Сиве, прашњаве 'гимнастјорке', шињели. На шлему петокрака. 'Товариши!' - из подрума полупорушене куће искачу људи, жене, деца, грле сасвим младог совјетског капетана. Све је више људи. Међу њима и ја. Прилазим капетану: 'Друже капетане, тамо горе,

78 Детаљније о томе видети: Popović N., Jugoslovensko-sovjetski odnosi u Drugom svetskom ratu (1941-1945), Beograd, 1988, str. 187-231.

79 У својим мемоарима Лобачев, који је као тумач у 57. армији дошао од Београда до Беча, није се устручавао, за разлику од велике већине руских аутора мемоара, да помене бројне случајеве пљачки и силовања које су починили припадници Црвене армије у Европи. Уосталом, он их није генерализовао већ их је описао као једну негативну појаву, са којом су се безуспешно борили војни, политички и безбедносни органи Црвене армије. Лобачев Ђ., Kag се Воліа уливала у Саву, Београд, 1997, с. 139, 144, 149, 157, 169. 
иза булевара је митраљеско гнездо. Немци су још тамо. Али може се преко рушевина неприметно проћи. Ходите, показаћу вам.' 'У реду, покажите!' И војницима: 'За мном!' Од прозора полусутерена напола срушене куће до врата митраљеског гнезда око петнаест метара. Капетан тихо каже: 'Коља, давај! (Коља, хајде)'. Мали плећати војник прилази прозору, пљунуо је у шаке, узео гранату, тренутак као да ју је вагнуо и хитнуо кроз прозор. Врата су избијена. Друга, трећа граната. Пут је отворен. Али сад се треба пробити кроз гомилу света, кога је све више. У рукама цвеће, чутуре, флаше. Грле војнике, зову у госте, заборавили су да је ослобођење града тек почело. И тако је било свуда: често на једном крају улице се још води борба, а на другом крају, већ ослобођеном, прозори са полупаним стаклима се украшавају ћилимима, од раније спремљеним тробојкама, црвеним заставама, и раздрагани људи грле борце-ослободиоце. ${ }^{\text {"80 }}$

Црвеноармејци осим Београда учествовали су и у ослобађању српске културне престонице - Новог Сада. Извиђачка група маринаца Дунавске флотиле, под командом искусног диверзанта Виктора Калганова званог „Брада“, 22. октобра 1944. ушла је у Нови Сад, који су у то време већ напуштале последње немачке јединице. Ево како је тај подухват описао капетан бојног брода Аркадиј Свердлов, начелник штаба Дунавске флотиле: „Изненађујуће лако заузели смо дунавски градић Нови-Сад. Тамо је био избачен мањи извиђачки десант - осам маринаца и пет Југословена-добровољаца под командом поручника корвете В. А. Калганова. Заједно са извиђачима се искрцао и сарадник нашег штаба поручник фрегате Г. К. Чепижни. Када су се упознали са ситуацијом, извиђачи су закључили да Не-

80 Лобачев Ђ., Каg се Волїа уливала у Саву, Београд, 1997, с. 123-124. 
маца има мало и да су они углавном код пристаништа. Маринци су одлучили да нападну. Изненадни јуриш је запањио непријатеља. Преживели Немци пожурили су на чамце и побегли. Оставивши другове Југословене да чувају барже са непријатељском војном опремом које је оставио непријатељ, маринци су ушли у град. Калганов и Чепижни су се обратили окупљеним грађанима и рекли су им: Град је слободан, фашисти овде више неће доћи“"81 Након тога власт у граду је преузео Новосадски партизански одред, а следећег дана у град су ушле и редовне јединице VII војвођанске ударне бригаде НОВJ: „Да би испитао ситуацију у Новом Саду и услове за пребацивање бригаде преко Дунава, помоћник комесара бригаде, Душан Секић Шаца и обавештајни официр Главног штаба Војводине, Радован Новић Цига, упутили су се са групом бораца у Нови Сад. Искрцавши се 24. октобра ујутро на пристаништу, они су се неочекивано нашли опкољени раздраганим и одушевљеним Новосађанима. Посадивши их у цвећем искићени фијакер, грађани Новог Сада су пошли за њима кличући слободи и нашој победи. На све стране вијориле су се црвене заставе и кретале поворке грађана. У центру града састали су се са члановима штаба Новосадског партизанског одреда, који су претходног дана ушли у напуштени Нови Сад“. ${ }^{2}$

У овим описима као и у другим успоменама српски град је представљен као једно релативно мало место уз општу позитивну слику и одређено занемаривање значаја самог града и погледа са висине на партизанске снаге. Уосталом, овај поглед на партизане није носио карактер увреде или непријатељства и није излазио са границе обичног другарског супарништва погле-

81 Свердлов А. В., Войлощение замысла, Москва, 1987, с. 119.

82 Божић Н., Сеgма војвођанска НОУ бриїаgа, Београд, 1984, с. 228. 
да који је био типичан у Црвеној армији у ривалству маринаца („црна смрт“), пешадије („чизмаши“), тенкиста („дизелаши“) итд. Као негативан индикатор осећања и емоција које су стекли црвеноармејци о Југославији и Југословенима може се навести књига Ореста Маљцева Јуїословенска йраїеgија. Реч је о квазиуметничком делу, заправо пропагандном памфлету из доба ИБ-а, у коме је описано све негативно, црно и критично што су ангажовани совјетски аналитичари успели да ископају у вези са југословенским комунистима и њиховим вођством. Ипак, чак и у овом раду, крцатом бројним истинитим и неистинитим оптужбама, не може се пронаћи ниједан лични негативан доживљај совјетских војника који су се у јесен 1944. нашли у Југославији. ${ }^{83}$ Позитивни утисак о Југославији остао је не само у колективној свести црвеноармејаца III украјинског фронта већ и код војника који су добијали неформалну информацију о томе из „војничког телеграфа“ - гласина и разговора са саборцима. Према успоменама, војници који никад нису били у Југославији су 1945. из званичних саопштења и разговора „упијали најмање нијансе информација. Није нам било лако. Саосећали смо са онима који су били у Будимпешти и код Берлина, завидели смо у позитивном смислу онима које су одушевљено дочекали Југословени и Чеси. Читав рат је био дубоко преживљен и остајао је у души“. 84

На основу доступног материјала може се извести општи закључак о позитивним успоменама које су сачували совјетски војници о сусрету са становништвом српских градова у источном делу Југославије. Позитивна слика створена у то доба у масовној свести руског

83 Мальцев О., Юіоолавская тираїеgия, Москва, 1952.

84 Красноармеец Кожин Юрий Алексеевич (http://www.iremember. ru/content/view/38/8/1/1/lang,ru/). 
народа надживела је комунистичку идеологију, СССР и СФРЈ, помогла је обнављању старих традиционалних симпатија затртих за време „пролетерских баханалија“ двадесетих и почетка тридесетих година и пружила добру основу за позитивну слику о Србима код савремених Руса.

Резиме: Објективни и мање објективни разлози су утицали на расположење совјетских војника према становништву Југославије. Према успоменама учесника рата, међу совјетским војницима и цивилима 1941-1943. постојао је драматичан осећај усамљености СССР-а у борби против Немаца и њихових савезника. Овај осећај узалуд је покушавала да сузбије званична совјетска пропаганда. Зато је онај ко се такође борио против Немаца од 1941. на сопственој територији, бранећи своје огњиште, природно стицао код совјетских војника позитиван имиџ. Позитиван однос према Југославији види се и из мемоара совјетских учесника борби у Југославији, где се могу наћи одушевљени описи југословенске природе (појава иначе нетипична за совјетске ратне успомене). Према успоменама, војници који никад нису били у Југославији су 1945. из званичних саопштења и разговора „упијали најмање нијансе информација. Није нам било лако. Саосећали смо са онима који су били у Будимпешти и код Берлина, завидели смо у позитивном смислу онима које су одушевљено дочекали Југословени и Чеси“. У овом контексту веома индикативан је однос према српским градовима, као градовима народа који се борио против заједничког непријатеља. С друге стране, постоји више примера снисходљивог сагледавања мањих димензија српских градова, и релативно мирног заузимања већине ових градова. У раду се упоређује ситуација која је пратила улаз Црвене армије у три српска града - Крушевац, Београд и Нови Сад, као примере града у унутрашњости уже Србије, главног града Србије и града у Српској Војводини. 
Резюме: Объективные и субъективные причины влияли на отношение советских военнослужащих по отношению к населению Югославии. По воспоминаниям участников войны, среди советских военных и гражданских в 1941-1943 г. присутствовало драматическое чувство одиночества СССР в борьбе с немцами и их союзниками. Это чувство пыталось уменьшить официальная советская пропаганда, расписывая эпизодические столкновения союзников с немцами или одиночные случаи диверсий повстанцев на территории оккупированной Европы. Вот почему народ, который действительно сражался против оккупантов с самого 1941 г., защищая свой очаг, естественно, вызывал уважение и симпатии со стороны советских солдат. Позитивное отношение к Югославии можно обнаружить в мемуарах советских участников борьбы в Югославии, сохранивших восхищенные описания югославской природы и городов (натурные зарисовки в воинских мемуарах не были частыми в советской военной традиции). Согласно воспоминаниям, солдаты, которые никогда не были в Югославии в 1945 году из официальных заявлений и разговоров, впитывали малейшие крохи информации об этой стране, сочувствовали тем, кто был в Будапеште и Берлине, завидовали нас в положительном смысле тем, кого тепло встречали сербы и чехи. В этом контексте отношение к сербским городам, как городам людей, которые сражались против общего врага, очень показательно. При этом, конечно были примеры снисходительности в наблюдениях за небольшими городками Сербии, из-за их небольших размеров и сравнительной легкости овладения этими городами. Наиболее интересно сравнить освобождение Красной Армией (совместно с партизанами) трех сербских городов - Крушеваца, Белграда и Нови-Сада, в качестве примеров города в глубине Сербии, столицы Сербии и столицы сербской Воеводины. 
Aleksej Timofejev, $\mathrm{PhD}$

\section{PICTURE OF THE SERBIAN CITY IN THE MEMORIES AND DOCUMENTS BY THE MEMBERS OF THE RED ARMY IN THE AUTUMN 1944.}

Objective and less objective reasons influenced on the mood of Soviet soldiers according to the population of Yugoslavia. According to the memories of the participants of the war, among Soviet soldiers and civilians 1941-1943.

there was a dramatic sense of loneliness of the USSR in the struggle against the Germans and their allies. This feeling in vain was trying to suppress the official Soviet propaganda.

That is why the one who also fought against the Germans since 1941 in his own territory, defending his hearthstone, naturally gained a positive image among the Soviet soldiers. A positive attitude towards Yugoslavia can be seen from the memoir of Soviet participants in the struggle in Yugoslavia, where you can find enthusiastic descriptions of the Yugoslav nature (a phenomenon that is not typical for Soviet war memories). According to memories, soldiers who never came to Yugoslavia in 1945, are from official statements and interviews absorbed the least nuances of information. „It was not easy for us. We felt compassionatewith those who were in Budapest and Berlin, we were envious, in a positive meaning, to those who were enthusiastically greeted by the Yugoslavs and the Czechs." In this context, the attitude towards Serbian cities, as the cities of the people that fought against the common enemy, is very indicative. On the other hand, there are more examples of the seeing the smaller dimensions of Serbian cities, and relatively peaceful occupation of most of these cities. This paper compares the situation that followed the entrance of the Red Army into three Serbian cities - Kruševac, Belgrade and Novi Sad, as examples of the city in the interior of Serbia, the capital of Serbia and the city in Serbian Vojvodina.

Key words: World War II in Serbia, Serbian society in war, Red Army, imagology, Russian-Serbian relations. 